\title{
Citizenship Education for the Blossoming of Participatory Democracy
}

\author{
María de Lourdes Lara Hernández, $\mathrm{PhD}^{1}$, Sol Cristal Molina Parrilla ${ }^{2}$ \\ ${ }^{1}$ Department of Social Sciences, University of Puerto Rico, Humacao, Puerto Rico, maria.lara1@upr.edu \\ ${ }^{2}$ Department of Social Sciences, University of Puerto Rico, Humacao,Puerto Rico, sol.molina@upr.edu
}

\begin{abstract}
This research had the objective of exploring the impact of education in citizens' competences, whilst using the Participatory-Action-Research (PAR) methodology-created by the sociologist Orlando Fals Borda (1970) — on leaders that work with teens in impoverished and marginalized communities. The study explores the impact of the training on five NGO's in citizens competences for the empowerment and promulgation of participatory democracy. We expected to scrutinize PAR's methodology and the training in citizens competences with content and other methodologies that transform the research practices and encourage citizen's empowerment. By practicing the seven phases of PAR, we designed surveys, conducted interviews and visited five NGO's that offer educative services in Puerto Rico to identify their needs. We facilitated workshops on cognitive, emotional, social and communicative competences - according to their felt-expressed needs. Afterwards, we designed and implemented evaluations using participatory methodologies. The results indicate they incremented in 75 percent their consciousness, knowledge and strengthened their ability to make individual and collective decisions. It led them to a sense of empowerment as citizens and leaders that can play a role in the development of democratic practices in their NGO's, their community and the public policy education of their country. They recognize, in over 80 percent of their responses, the need of incorporating participatory methodologies as well as citizens' competences to their programs and curriculums. Also, they suggested the board of directors should be trained on these methodologies and contents, in order to transform the NGO's that serve disadvantaged communities.
\end{abstract}

KEYWORDS: PAR, citizens competences, participatory democracy, empowerment

\section{Introduction}

Puerto Rico is a colony of the United States, an indebted country with high levels of social and economic inequality (Instituto de Estadísticas 2015). Young adults between the ages of 18 to 34 years in Puerto Rico are one of the more vulnerable groups in the country that reflect high indicators of poverty, social insecurity and marginalization (SOMOSelAHORA 2016). This situation responds to high levels of social and economic disparity while being a product of government corruption, bankruptcy and the political-colonial status of the country.

The Fundación Agenda Ciudadana (FAC) is an NGO dedicated to the social transformation of Puerto Rico reinforcing the compromise of all sectors of society. This social transformation is based in a common vision of a shared future. The core values of this future are: sustainable development, investment in education, social inclusion and the strengthening of alliances (Agenda Ciudadana 2012; 2016). All these values help formalize and offer follow-up to proposals that academic, corporate, governmental sectors and citizens initiated and worked for the past 12 years.

FAC looks to improve citizen, public, private and NGO power before the partisan tribalism. It strives to take on a leading role in the creation of a new Puerto Rico of social and economic prosperity; generator of ideas, public policy and consultancy. It promotes the development of curriculums and educational programs in citizens competences. All from alternative and creative methodologies for all populations.

The University of Puerto Rico in Humacao (UPRH), through its Bachelor's in Social Sciences in the methodology of Participatory-Action-Research (PAR), provides tools to assure the compromise and accountability of all the sectors that commit to attend felt-expressed needs. It identifies research areas that are necessary and uses its results to understand and solve problems. Simultaneously, it has been reforming in a repository of research and successful practices that come from different and alternative learnings. 
The convention that has been developed between Fundación Agenda Ciudadana (FAC) and the University of Puerto Rico in Humacao (UPRH) suppose the integration of learnings, methodologies, relations and strategies that accomplish transformations in the practices, visions and values of the groups and institutions with whom they work. They educate in an alternative manner for different and creative results that facilitate new forms for the empowerment of the country.

In order to attend this purposely hidden need in Puerto Rico and acknowledging the potential of this group to rebuild the country through the exercise and promotion of the participatory democracy, the FAC and the UPRH initiated a Participatory-Action-Research (PAR) project with the following objectives:

1. Research citizens competences (cognitive, emotional, communicative and social) that promote a bigger activation and mobilization from community organizations that serve children and young adults with high levels of exclusion and poverty.

2. Identify and document practices that community organizations realize to facilitate citizen education as a way to promote for a democracy that's more participative and redistributive.

Some of the questions that guided this project were:

1. How citizens competences promote the activation and mobilization of organizations/institutions that work with populations with high levels of exclusion and poverty? How can we raise awareness or help on the development of conditions for social change?

2. Which practices and competences have developed a more democratic and participative character on organizations that are being educated on these skills?

Consequently, this paper pretends to summarize the findings and share some suggestions that we believe can contribute to the discussion and reflection in educational centers for the promotion of participatory methodologies in the development of community leaders and young adults that suffer marginalization and inequality in Puerto Rico and internationally.

\section{Framework and theory}

We recognize and promote citizen participation as one of the main vehicles for social change and individual and collective empowerment. We can define empowerment as the process by which individuals, groups, organizations and communities develop a sense of control over their lives, allowing them to act efficiently in the public sphere, and also allowing them to access resources and promote changes in their common contexts (Ortiz-Torres 1999, 52). Through effective citizen participation they are trying to transform the traditional representative democracies in participatory democracies in which citizens have a greater role in public administration.

We agree with Castells (1982) and Velázquez (1986) in that participation is a social process of inclusion of social stakeholders as to directly or indirectly influence the development of society and its systems. Sanchez (2000) suggests three or four inclusion criteria or indicators in the different stages in which citizens are involved in the decision-making of its affairs or matters pertaining to the social group or community. These range from: the power to influence without specifying at what level; attend meetings or assume leadership positions; or intervene in decisionmaking, to be part of the planning, management, and use of resources. Later it presents other indicators such as participatory design (Stringer 1982), educational interaction (Lawrence 1982) and the emphasis on the values of autonomy, cooperation, and consistency that require conditions such as the social constructs of designing political participation; and receiving these designs are moulded in an interpersonal relationship (participatory design), who has a learning experience for all sectors involved (educational interaction), and that this interaction between professionals, government officials, and others, allow the communities to hold their positions and recommendations of their needs in a spirit of respect and cooperation, while allowing control by users to make decisions without dissent or be subjected to reprisals such as exclusion. 
These authors start from the basic tenets of what a democratic system is, to the point of describing another level of democratic system such as the Participatory Democracy. A system that promotes participatory democracy is defined as such if it meets the following criteria: universality, participation, truthful information, and access to and control of resources (Muñoz 2004) considered social or common property to all in a society. These conditions and levels of implementation determine the levels of participatory democracy that it exhibits. We shall define each.

Universality means the ability of every individual to have access to rights guaranteed by the community simply by being considered a rational person. (The impersonality that Max Weber refers to). Thus, the universality of the rights of citizens entails some obligations to ensure that they are not subject to the whims or the desires of their government officials (Muñoz 2004). If some groups are legitimated over others to be entitled to participate because they have some education, are of a particular social class, or occupy a particular position in the social work sphere, politics, or the principle of universality, they are neutralized.

By participation (from the postulates of democracy in general) we understand not only being in an electoral register but the opposite; collaborating in the democratic control of those institutions in which effective decision-making (Muñoz 2004) is made. Participation, therefore, has to be understood not only as a political process, but also economic, social and cultural processes are essential elements in the intervention of citizens in the administration of society. So, for example, participation in public hearings on government decisions is one of many possible participation exercises.

Truthful information, Muñoz (2004) explains is "information as to the explanation and clarification of causes. It requires the absolute defence of the principle of autonomy of conscience of citizens. Consequently, the search for a society in which collective relations are established as free and equal ensure that the principle of autonomy protects the capacity of action, reflective thinking, and awareness of individuals." (pg. 7). There are several conditions involving this principle including: that citizens have the information, the information is complete and accessible, and for citizens to maintain their independence of criteria assumed positions about them. If one of these conditions is not present, the others are neutralized. According to the author, control of use and distribution of resources is concerned with, "the management of the means for a physical and mental development of the community as a whole" (pg.7) and this is nothing else than enabling users or members of a society to have the right to share decision-making about resource management of that company or to be those who administer it.

Those are the basic conditions of what we call strong democracy or deliberative/participatory democracy (Barber 1998; Muñoz 2004). It is one in which citizens have the capacity to act, receiving truthful information and, at the same time, harness their areas of cooperation and social collaboration. Strong democracy is based on participation in a dynamic community solving problems, which creates public purposes, where none existed before, through its own activity and its own existence as a focal point in the search for mutual solutions. In such communities, the authors state, public purposes are either not extrapolating from absolute or are discovered hidden in a pre-existing consensus. They are literally forged by the act of public participation under the joint deliberation, the joint action, and the effect of this action and this deliberation, which change shape and direction when subjected to these deliberative processes.

This Participatory Democracy also meets requirements that further this practice. Barber (1998) highlights the following: (1) distribution of power through participatory policy and decision making at all levels in which you can participate (planning, management, resource management, monitoring, etc.); (2) political action understood as a corrective to the inequality; that is, that the state can mediate and manage actions to ensure the inclusion of the differences or take action if they are expressed and affect the participation of individuals or groups; (3) ensuring consensus through public deliberation. Here it is argued that there are no solutions or ideas that include or guarantee the rights and needs of all, that social problems are complex, so it should be kept in open dialogue, critical to the positions and decisions taken between everybody. 
Effective participation enables the development of individual skills; promotes the organization and activation of individuals, groups, and communities; and facilitates the transformation of shared contexts by those involved in the participatory process (Ortiz-Torres 1999; Lara 2007; Rappaport 1981). As proposed in the definition presented, the changes that are promoted through participatory processes should eventually allow greater access to resources of all kinds.

\section{Methodology}

This project had the Participatory-Action-Research (PAR) frame - one that is epistemological and methodological. This methodology allows to have a proximity to the comprehension and intervention of complex phenomena (Morin 2004), through a dialectic process of research-action-reflection (Fals Borda 1978). All its phases occur with the active participation of the involved subjects in a subject-subject relationship between researchers and those who are being researched (Fals Borda, 1981). In this relationship, the public issue to be addressed is defined, new learnings are developed and strategies for its transformation are agreed on (Fals Borda, 1978; Montero 2005).

In PAR, the active and direct participation of the implicated groups is promoted-this facilitates a subject-subject relationship and disrupts the subject-object relationship proposed by the traditional research (Fals Borda, 1987). This methodology validates popular learnings along with academic learnings and allows the creation of a transdisciplinary approach towards complex phenomena that interfere in society (Morin 1990; Jara 2015; Lara 2007). Simultaneously, it eases the empowerment process that results in the increase of participation and social action levels of citizenship (Montero 2005; Sánchez 2000). The project created a transectorial team of researchers to profile and capacity building needs of five NGOs that work with young adults-who have abandoned school and live in marginalized communities - from an alternative education model. These five NGOs promote education as a way for these young adults to complete secondary education and a training in vocational skills that allow them to be a part of the working world. To this group, a PAR team of six research students - from the Bachelor's in Social Sciences focused in PAR in UPRH - and the team of FAC were added.

The phases of the action-research project are summed up in:

1. Identifying the felt-expressed need by each of the five NGOs to collectively design a training and coaching program (participative diagnostic).

2. Training of leaders and allies of each NGO in citizens competences.

3. Learnings transference process to other participants (educative mentoring).

4. Follow-up to the changes in each NGO for the measuring of their activation and mobilization levels.

5. Processes systematization for the redaction of recommendations.

In order to achieve effective actions as citizens it is crucial to know and know-how, this is, to know and act from the citizens competences. They have a great impact in our daily life and decide if they will be of benefit to the community and society as an assemblage. Do we know what citizens competences are? Do we act, relate and mobilize according to them? How do we know which decisions and actions can benefit us and which encroach against the common good? These are some of the questions that we need to make when we talk about citizens competences. The democracy and active-participative citizenship are proposed as a vital issue in these times where citizens rights and the state's responsibilities are fragilized and torn down. Could we act differently in order to achieve more supportive, just and equitable societies? How can citizens competences contribute to attain it?

Citizens competences have been defined as those cognitive, emotional and communicative abilities, learnings and attitudes that, joined with each other, incite people to act in a constructive manner in a democratic society. They allow citizens to actively contribute in a pacific coexistence, responsibly and constructively participate in democratic processes and understand plurality as an opportunity and resource of society-both on intimate milieus (family, friends, school) and 
community, country or internationally. For a basic education in these competences we can include these four basic topics: 1) citizen participation; 2) human rights; 3) conflict management and reinforcement of social skills; 4) acknowledgement of our differences and solidarity (Ruiz \& Chaux 2005).

\section{Identification of the felt-expressed need of the five NGOs (participative diagnostic)}

By the felt-expressed petition, at the end of 2016, we designed a pilot program of "Capacitación de Capacitadores en Competencias Ciudadanas" directed to the staff and board of directors of five NGO's from the "Alianza Para la Educación Alternativa" (AEA). This program was designed while acknowledging the socioeconomic and political context of Puerto Rico. The NGO's from the AEA offer services to this population, mainly, offering alternative education models that potentiate their knowledge, skills, abilities and their integral development as human beings.

In light of the fiscal and democratic crisis, the board of directors from the AEA acknowledged the need of rethinking their models and strategies; to train themselves in order to train their participants in citizens competences so they can exert their citizenship and potentiate the changes the country needs.

\section{Training in citizens competences of leaders and partners of each NGO}

The Program initiated in May and continued until the week before Hurricane María. The training could not be completed since the NGOs had to dedicate their efforts to aid affected communities by the hurricane. Even then, we were able to offer between eight to 24 hours of training and educative mentoring in citizens competences identified as necessary for each NGO.

We administered an evaluation to each participant at the end of each training. This evaluation included three areas: 1) new learnings; 2) concepts to look into and 3) actions which they would commit to further pursue the skills and learnings acquired throughout the Program. This was also a participatory exercise since it encouraged the reflection of their learning process and capacity to take action in each participant (individually and as a collective).

Five months after Hurricane Maria made landfall, on January 24 of 2018, we agreed to continue with the evaluation process of the Pilot Program, proposed the administration an impact evaluation and coordinated a pedagogic closeup to offer follow-up recommendations.

\section{Learnings transference process to other participants}

We designed an evaluation instrument with the objective of measuring the results and impact of the workshops. These instruments have two parts: the first one is specific for each NGO. This section was built from the answers given by them in the training evaluations. Based on the categorization and the summary of the answers to the evaluations, we prepared a list of premises for each organization to be validated by the participants on the impact evaluation. The second part featured open questions, so we could acquaint, after 8 months of receiving the workshops, learnings that have been implemented in their NGO's workspaces, learnings that need to be strengthened, challenges that have been faced in their execution and what suggestions they might have for their NGO and/or us.

The Evaluation revealed that the participants expressed which learnings were acquired from citizens competences; the diversity of knowledge, skills and abilities a competent citizen must have. They informed to comprehend the difference between civic education and citizen education and understood the need of transforming the practicums and curriculums for the inclusion of some of the citizens competences in their NGO. Also, they expressed a need and interest in expanding their knowledge in citizens competences, particularly in specific skills such as: active listening, empathy and dialogue, so they can achieve an implementation to their personal and collective lives, work and community scenarios. Additionally, we had the following results:

1. Over 75 participants were trained in Citizens Competences.

2. Four of the five NGOs received over 16 hours of training associated to their felt-expressed needs.

3. We successfully designed and implemented surveys and training modules. 
4. Various NGOs had the opportunity of being trained in Total Language (a methodology that integrates the three competences) and were able to facilitate these competences on their region as a way of having a live formation experience and used it after the hurricane Maria impact their regions.

5. A $100 \%$ of participants expressed to have learned what citizens competences are; the diversity of learnings, skills and abilities that a competent citizen should possess.

6. A $100 \%$ of participants understood they learned pedagogic strategies to strengthen and encourage.

7. $85 \%$ of the participants informed they understood the difference between civic education and citizen education.

8. $75 \%$ of the participants comprehend the need of transforming their NGOs practices and curriculums for the inclusion of citizens competences.

\section{Identified Challenges}

With the objective of evaluating the experience, we summarized some of the challenges for the fulfillment of certain phases of the Program. The initial meeting with the NGOs reached execution in April 2017 and led to the delay of the whole implementation calendar - which was established and approved since January 2017. Therefore, the beginning of the workshops overlapped with the summer break. During this period, we were able to train two of the NGOs. However, the other NGOs requested scheduling their workshops during August 2017 - the beginning of the academic semester.

The initial goal, that all the members of the board of directors from the NGOs of the AEA were impacted, wasn't fulfilled completely. The NGOs, though interested in the competences, sent direct service personnel to the workshops, which hampered achieving influence in the decisionmaking of practices and curriculum changes of the NGOs towards leadership, active citizenship and self-managed models. Only the Executive Director of one of the NGOs participated in the introductory workshop.

On the other hand, the passing of Hurricane Irma, and then Hurricane Maria, during September 2017, disrupted the offering of the remaining workshops. For one of the NGOs, we were not able to coordinate their workshops. Because of the national emergency, the NGOs redirected their attention to respond to the urgent needs of the populations they serve. In the same way, FAC coordinated regional encounters in which, while using Total Language methodology, we facilitated a reflection process from the experience of the hurricane till the co-creation of strategies for the transformation of Puerto Rico as of its regions. We facilitated four regional encounters in which part of these NGOs participated as facilitators.

This event limited the offering of the coaching and the follow-up to the NGOs for their practical implementation and transference of the citizens competences to their lives, organizational structure and with the participants in their service centers.

The day to day basis of each NGO and their constant practice of focalizing on handling the urgent issues, maintained them with a difficulty of reflecting on what they needed to know and know-how, in terms of doing more and achieving transformative changes in less time with limited resources - as demanded by the times of crisis that we faced as a country. Models that include citizens competences and the training of trainers can achieve these objectives without the necessity of onerous investments for the personnel and the NGO.

Other challenges that the participants experienced in their personal and work scenarios were:

1. Personal resistance towards change.

2. Changing habits and customs that collide with the citizens competences.

3. Developing the habit of active listening in order to comprehend other's feelings and viewpoints.

4. A space where we can nurture citizens competences.

5. Grappling with a resistant culture towards dialogue.

6. Time for training and reflection. 


\section{Conclusions and recommendations}

The participants understood some fundamental future actions for their personal and professional development: 1) independent and collective education in citizens competences for their personal growth and the NGO's; 2) be more active and conscious towards other's needs; 3) build up spaces for deliberation, discussions and forums about citizens competences; 4) engage collectively in activities for the understanding and appropriation of citizens competences; 5) redirect their structure for a transformation.

On the other hand, there are some fundamental future actions for FAC and UPRH:

1. Offer a complete course with coaching and with the commitment of participants (and their interest in participating).

2. Offer an educative coaching to the NGOs from the AEA and complete the workshops and topics requested in the evaluations.

3. Design and implement a training program in citizens competences for young students as a second phase of the program.

4. Design various training models (8-16-24-30 hours) to adapt them to the needs and conditions of the NGOs.

\section{Acknowledgments}

We acknowledge and give credit to the team of research students from the Bachelor's in Social Sciences specialized in the Participatory-Action-Research Methodology (PAR) of the University of Puerto Rico in Humacao: Andrea Pichardo Vázquez, Jean Saldaña Alicea, Kheyris Nieves Burgos, Liliana Rodríguez Márquez and Teisha Matta Flores.

Also, to the team of Fundación Agenda Ciudadana who actively participated since its design till the impact evaluation: Andrea Iguina Pérez, Elena Martínez-Torres and Liz Andújar Rodríguez.

We give recognition to the names of the participants in the program and the PAR from the five NGOs: Aspira, Centros Sor Isolina Ferré, Mentes Puertorriqueñas en Acción, Nuestra Escuela and Proyecto Nacer.

Lastly, yet not less important, we thank the sponsorship for the whole research and offered trainings to the Fundación Ángel Ramos, whom also worked in the identification of the feltexpressed needs in the NGOs that participated and offered spaces and technical support for the execution of the project.

\section{References}

Barber, B. 1988. Un marco conceptual: politica de la participación [A conceptual framework: politics of participation]. In Águila R. \& Vallespin.

Castells, M. 1982. Politica urbana, participación ciudadana y movimientos vecinales [Urban politics, citizens participation, local movements]. Dictated conference in the Architecture and Urbanism Faculty of the Universidad Central de Venezuela, Caracas. (Photocopy).

El Nuevo Día. 2012. Agenda Ciudadana 2012 [Citizens Agenda 2012]. El Nuevo Día. Guaynabo, Puerto Rico. Retrieved from: http://www.agendaciudadanapr.com/publicaciones/

El Nuevo Día. 2016. Agenda Ciudadana 2016 [Citizens Agenda 2016]. El Nuevo Día. Guaynabo, Puerto Rico. Retrieved from: http://www.agendaciudadanapr.com/publicaciones/

Fals Borda, O. 1978. "Por la praxis: El problema de cómo investigar la realidad para transformarla" [By the praxis: The problem of how to research reality to tranform it]. In Crítica y politica en ciencias sociales [Critique and politics in social sciences]; El debate, teoría y práctica [The debate, theory and practice], vol. I, Bogotá, Punta de Lanza, 209-271.

Fals Borda, O. 1981. "La ciencia y el pueblo" [Science and the people], in O. Fals Borda, B. Hall, A. Vio Grossi, E. Cohen, G. Le Boterf, E. Rubin, J. Pierre, F. Grandoit, A Schutter, T. de Witt \& V. Gianotten, Investigación participativa, praxis rural [Participatory research, rural praxis], Lima, Mosca Azul, 19-47.

Fals-Borda, O. 1987. Investigación Participativa [Participatory Research]. Montevideo: La Banda Oriental.

Instituto de Estadísticas de Puerto Rico. 2015. Estado Libre Asociado de Puerto Rico Census Bureau [Commonwealth of Puerto Rico Census Bureau]. http://factfinder2.census.gov/.

Jara, O. 2015. Dilemas y Desafios de la Sistematización de Experiencias [Challenges and dilemmas of the Experiences Systematization]. Centro de Estudios y Publicaciones Alforja. Costa Rica. 
Lara, M. 2007. Al Margen de los Márgenes: Complejidad y Transdisciplinariedad en la Relación UniversidadComunidad [At the Margin of Margins: Complexity and Transdisciplinarity on University-Community Relationship]. Editorial Koiné. San Juan, Puerto Rico.

Lara, M. 2007. Democracia Participativa, Privatización y Cambio Social [Participatory Democracy, Privatization and Social Change]. Disertación doctoral sometida a la Escuela Graduada de Psicología en Recinto de Río Piedras de la Universidad de Puerto Rico.

Lawrence, E. 1982. Designers' dilemma: Participatory Design; cited in Sánchez, E. 1982. Todos con la Esperanza: Continuidad de la participación comunitaria [All with the Hope: Continuity of community participation]. UCV. Caracas, Venezuela.

Montero, M. 2005. Hacer para Transformar: el método en la psicología comunitaria [Do to Transform: the method in community psychology]. Editorial Paidós. Barcelona.

Morin, E. 1990. Introducción al Pensamiento Complejo [Introduction to Complex Thought]. Editorial Gedisa.

Barcelona.

Morin, E. 2004. Introducción al pensamiento complejo [Introduction to complex thought]. México, D. F.: Editorial Gedisa.

Muñoz, B. 2004. Sobre el quiebre en la Democracia Participativa [About the breakage in Participatory Democracy]. Nómadas: enero-julio num. 009, (2-17) Universidad Complutense, Madrid.

Ortiz-Torres, B. 1999. El empowerment como alternativa teórica para América Latina [Empowerment as a theoretical alternative for Latin America]. Revista Interamericana de Psicología, 33, 49-65.

Rappaport, J. 1981. "In praise of paradox: A social policy of empowerment over prevention." American Journal Community Psychology 9: 1-25.

Ruiz, A. \& Chaux, E. 2005. La Formación en Competencias Ciudadanas [The formation in Citizens Competences]. Ascofade. Bogotá, Colombia.

Sánchez, E. 2000. Todos con la Esperanza: continuidad de la participación comunitaria [All with the Hope: Continuity of community participation]. UCV. Caracas, Venezuela.

SOMOSelAHORA. 2016. Retrieved from https://www.somoselahora.com/

Stringer, P. 1982. Towards a participatory Psychology; cited in Sanchez, E. 2000. Todos con la Esperanza: Continuidad de la participación comunitaria [All with the Hope: Continuity of community participation]. UCV. Caracas, Venezuela.

Velásquez, F. E. 1986. La participación ciudadana en la planificación urbana: trampa ideológica o posibilidad democrática? [Citizens participation in urban planning: and ideological trap or a democratic possibility?]. Boletín Socioeconómico de la Facultad de Ciencias Sociales y Económicas de la Facultad del Valle de Cali, Colombia, 16, 73-97. 